\title{
Safety and efficacy of mTOR inhibitor treatment in patients with tuberous sclerosis complex under 2 years of age - a multicenter retrospective study
}

Afshin Saffari ${ }^{1}$, Ines Brösse ${ }^{1}$, Adelheid Wiemer-Kruel2 ${ }^{2}$, Bernd Wilken ${ }^{3}$, Paula Kreuzaler ${ }^{4}$, Andreas Hahn ${ }^{4}$, Matthias K. Bernhard ${ }^{5}$, Cornelis M. van Tilburg ${ }^{6,7,8}$, Georg F. Hoffmann ${ }^{1}$, Matthias Gorenflo ${ }^{9}$, Sven Hethey ${ }^{10}$, Olaf Kaiser ${ }^{11}$, Stefan Kölker ${ }^{1}$, Robert Wagner ${ }^{12}$, Olaf Witt6 ${ }^{6,7,8}$, Andreas Merkenschlager $^{5}$, Andreas Möckel ${ }^{13}$, Timo Roser ${ }^{14}$, Jan-Ulrich Schlump ${ }^{15}$, Antje Serfling ${ }^{13}$, Juliane Spiegler ${ }^{16}$, Till Milde $^{6,7,8}$, Andreas Ziegler ${ }^{1}$ and Steffen Syrbe ${ }^{1 *}$

\begin{abstract}
Background: Tuberous sclerosis complex (TSC) is a multisystem disease with prominent neurologic manifestations such as epilepsy, cognitive impairment and autism spectrum disorder. mTOR inhibitors have successfully been used to treat TSC-related manifestations in older children and adults. However, data on their safety and efficacy in infants and young children are scarce. The objective of this study is to assess the utility and safety of mTOR inhibitor treatment in TSC patients under the age of 2 years.

Results: A total of 17 children (median age at study inclusion 2.4 years, range 0-6; 12 males, 5 females) with TSC who received early mTOR inhibitor therapy were studied. mTOR inhibitor treatment was started at a median age of 5 months (range 0-19 months). Reasons for initiation of treatment were cardiac rhabdomyomas (6 cases), subependymal giant cell astrocytomas (SEGA, 5 cases), combination of cardiac rhabdomyomas and SEGA (1 case), refractory epilepsy (4 cases) and disabling congenital focal lymphedema (1 case). In all cases everolimus was used. Everolimus therapy was overall well tolerated. Adverse events were classified according to the Common Terminology Criteria of Adverse Events (CTCAE, Version 5.0). Grade 1-2 adverse events occurred in 12 patients and included mild transient stomatitis (2 cases), worsening of infantile acne (1 case), increases of serum cholesterol and triglycerides (4 cases), changes in serum phosphate levels (2 cases), increase of cholinesterase (2 cases), transient neutropenia (2 cases), transient anemia (1 case) , transient lymphopenia (1 case) and recurrent infections (7 cases). No grade 3-4 adverse events were reported. Treatment is currently continued in 13/17 patients. Benefits were reported in 14/17 patients and included decrease of cardiac rhabdomyoma size and improvement of arrhythmia, decrease of SEGA size, reduction of seizure frequency and regression of congenital focal lymphedema. Despite everolimus therapy, two patients treated for intractable epilepsy are still experiencing seizures and another one treated for SEGA showed no volume reduction.
\end{abstract}

Conclusion: This retrospective multicenter study demonstrates that mTOR inhibitor treatment with everolimus is safe in TSC patients under the age of 2 years and shows beneficial effects on cardiac manifestations, SEGA size and early epilepsy.

Keywords: Tuberous sclerosis complex, mTOR inhibitor, Everolimus, Children, Neonates

\footnotetext{
* Correspondence: steffen.syrbe@med.uni-heidelberg.de

${ }^{1}$ Division of Child Neurology and Metabolic Medicine, Center for Paediatrics

and Adolescent Medicine, University Hospital Heidelberg, Heidelberg,

Germany

Full list of author information is available at the end of the article
}

(c) The Author(s). 2019 Open Access This article is distributed under the terms of the Creative Commons Attribution 4.0 International License (http://creativecommons.org/licenses/by/4.0/), which permits unrestricted use, distribution, and

reproduction in any medium, provided you give appropriate credit to the original author(s) and the source, provide a link to the Creative Commons license, and indicate if changes were made. The Creative Commons Public Domain Dedication waiver (http://creativecommons.org/publicdomain/zero/1.0/) applies to the data made available in this article, unless otherwise stated. 


\section{Background}

Tuberous sclerosis complex (TSC) is an autosomal dominant neurodevelopmental disorder caused by loss-of-function mutations in the TSC1 and TSC2 genes, encoding the Tuberin-Hamartin complex, acting as a critical upstream suppressor of the mammalian target of rapamycin (mTOR), a key signaling pathway controlling cellular growth and metabolism. TSC is a multisystem disease, and about $90 \%$ of individuals develop central nervous system complications, such as epilepsy, cognitive impairment and autism spectrum disorder $[1,2]$. Epilepsy, usually starting during the first 3 years of life, occurs in $83.5 \%$ of affected patients and represents the most prevalent and challenging clinical manifestation of TSC [2, 3]. Early-onset epilepsy typically presents with focal seizures with or without secondary generalization often evolving into infantile spasms (IS) during infancy. IS or West syndrome, a severe epileptic encephalopathy characterized by epileptic spasms and a pathognomonic EEG pattern (hypsarrhythmia), occurs in $38.8 \%$ of TSC patients [3]. Antiepileptic treatment with vigabatrin or adrenocortictropic hormone (ACTH) has proven to stop IS in $71.5 \%$ of TSC patients [3].

mTOR inhibition is a promising molecular target for the treatment of TSC manifestations, including epilepsy and behavior. The mTOR inhibitors rapamycin (sirolimus) and everolimus have been increasingly used in TSC. Everolimus has gained approval for the treatment of TSC-related subependymal giant cell astrocytomas (SEGA) and renal angiomyolipomas. In a phase I/II clinical trial including 20 children with TSC-related refractory epilepsy above the age of 2 years, everolimus led to a median seizure reduction of $73 \%$ with only mild to moderate adverse effects [4]. Recently, the EXIST-3 trial showed a significant seizure reduction in a large cohort of TSC patients aged 2-65 years treated with everolimus [5] and led to the additional approval for the treatment of refractory focal seizures in TSC above 2 years of age.

TSC-related early-onset epilepsy in the first year of life and in particular infantile spasms (IS) are the most important risk factors for mental impairment and autism spectrum disorder. In TSC, $74.4 \%$ of patients with IS develop cognitive impairment, while only $39.2 \%$ of patients without IS show neurologic deficits $[6,7]$. It can be hypothesized that early initiation of mTOR inhibitor treatment reduces the risk for TSC-related neuropsychiatric deficits [8-10]. However, data on safety and efficacy of everolimus treatment in infants and young children are still lacking and only one study analyzed clinical data of TSC patients treated with everolimus within the first 2 years of life [11].

The main purpose of this study is to collect data on the tolerability of mTOR inhibitors and the occurrence of adverse events in neonates and infants under 2 years of age. We further aimed at collecting preliminary data on the effects of mTOR inhibitor treatment on TSC-related malformations, epilepsy and neurodevelopment.

\section{Results \\ Cohort}

We collected data from 17 patients with a definite (clinical and/or genetic) diagnosis of TSC according to the 2012 International TSC Consensus Conference [12] (for clinical data see Table 1). Twelve patients were male, 5 female. Median age at inclusion into this study was 2.4 years (range 0-6 years). The median period of follow-up was 2.1 years (range $0.5-5.5$ years). Diagnosis of TSC was suspected prenatally due to cardiac rhabdomyomas in 14 cases and due to a SEGA in 1 case (patient \#12). Two patients initially presented with focal seizures and neuroimaging was suggestive of TSC (patients \#1 and \#16). In addition, we collected follow-up data in one case (patient \#14) that has been published previously [13].

Genetic analysis was carried out in 12 of the 17 cases. One child carried a mutation in TSC1 and 10 patients in TSC2. No mutation could be identified in patient \#17. No genetic information was available in the remaining 5 cases. TSC occurred sporadically in 15 patients while family history was positive in 2 patients.

Three patients were born pre-term due to cardiac complications (patients \#9, \#11 and \#13). All other patients were born at term with a normal birth weight and normal APGAR scores. Dermatologic manifestations were present in 11 cases, including white spots, facial angiofibromas, periungual fibromas, and a shagreen patch. Retinal hamartomas were present in 3 individuals. Two patients developed renal angiomyolipomas. Another patient showed an atypical manifestation with hemihypertrophy, congenital focal lymphedema of the leg, lumbar scoliosis and vascular anomalies including aneurysms and renal artery stenosis. Overall 14/17 patients $(82.4 \%)$ suffered from epileptic seizures. Seizure types included focal, generalized and atonic seizures, and in one case infection-related status epilepticus with Todd's palsy. IS developed in 7 cases (41.2\%) with a median age at onset of 5.5 months (range 1-7 months). Neuroimaging revealed tubers in $14 / 17$ patients $(82.4 \%)$, subependymal nodules (SEN) in 12 (70.6\%), and SEGA in 7 patients $(41.2 \%)$. Neuroimaging was normal in 2 cases (11.8\%). Initial neuropsychological assessment was normal in 5 of 14 tested children (35.7\%). Nine patients (64.3\%) showed various degrees of developmental delay. In 3 cases, no data concerning neurologic development were available.

Reasons for initiation of mTOR inhibitor treatment were symptomatic cardiac rhabdomyomas and arrhythmia in 6 (35.3\%), SEGA in $5(29.4 \%)$, the combination of cardiac rhabdomyoma and SEGA in 1 (5.9\%), refractory 
Table 1 Clinical data

\begin{tabular}{|c|c|c|c|c|c|c|c|c|}
\hline $\begin{array}{l}\text { Patient } \\
\#\end{array}$ & Sex & $\begin{array}{l}\text { Age at } \\
\text { inclusion [y] }\end{array}$ & $\begin{array}{l}\text { Age at } \\
\text { Diagnosis [d] }\end{array}$ & Mutation & $\begin{array}{l}\text { sporadic / } \\
\text { familial }\end{array}$ & $\begin{array}{l}\text { First clinical } \\
\text { manifestation }\end{array}$ & $\begin{array}{l}\text { Reason for mTOR } \\
\text { inhibition }\end{array}$ & Further manifestations \\
\hline 1 & $f$ & 4.3 & 210 & TSC2 & sporadic & Epilepsy & SEGA & $\begin{array}{l}\text { Neuro: tubers, SEN, migration } \\
\text { lines, DD }\end{array}$ \\
\hline 2 & $\mathrm{~m}$ & 6.2 & prenatal & $\mathrm{TSC2}$ & sporadic & $C R$ & $\begin{array}{l}\text { Congenital focal } \\
\text { lymphedema }\end{array}$ & $\begin{array}{l}\text { Skin: subungual fibromas } \\
\text { Neuro: Epilepsy, tubers, SEN, DD } \\
\text { Other: lumbar scoliosis, aneurysms, } \\
\text { renal artery stenosis }\end{array}$ \\
\hline 3 & $f$ & 0 & prenatal & NA & familial & $C R$ & SEGA & $\begin{array}{l}\text { Skin: angiofibromas, white spots, } \\
\text { Shagreen patch } \\
\text { Neuro: Epilepsy, tubers, DD }\end{array}$ \\
\hline 4 & $\mathrm{~m}$ & 0.1 & 49 & NA & sporadic & $C R$ & SEGA & $\begin{array}{l}\text { Skin: angiofibromas, white spots } \\
\text { Neuro: Epilepsy, tubers, DD }\end{array}$ \\
\hline 5 & $\mathrm{~m}$ & 1.5 & 60 & NA & sporadic & $C R$ & Epilepsy & $\begin{array}{l}\text { Skin: white spots } \\
\text { Neuro: tubers, SEN, DD } \\
\text { Other: retinal hamartomas }\end{array}$ \\
\hline 6 & $\mathrm{~m}$ & 0 & prenatal & $\mathrm{TSC2}$ & familial & $C R$ & $C R$ & None \\
\hline 7 & $f$ & 3.1 & prenatal & $\mathrm{TSC2}$ & sporadic & $C R$ & $C R$ & $\begin{array}{l}\text { Skin: white spots } \\
\text { Neuro: Epilepsy, tubers, SEN, DD }\end{array}$ \\
\hline 8 & $f$ & 5.1 & prenatal & NA & sporadic & $C R$ & SEGA & $\begin{array}{l}\text { Skin: white spots } \\
\text { Neuro: Epilepsy, tubers, SEN, white } \\
\text { matter lesions, DD } \\
\text { Other: retinal hamartomas }\end{array}$ \\
\hline 9 & $\mathrm{~m}$ & 4 & prenatal & $\mathrm{TSC2}$ & sporadic & $C R$ & $\mathrm{CR} / \mathrm{SEGA}$ & $\begin{array}{l}\text { Skin: white spots } \\
\text { Neuro: Epilepsy, tubers, SEN, } \\
\text { migration lines, DD }\end{array}$ \\
\hline 10 & $\mathrm{~m}$ & 4.1 & 30 & NA & sporadic & $C R$ & Epilepsy & $\begin{array}{l}\text { Skin: white spots } \\
\text { Neuro: tubers, SEGA, aberrant } \\
\text { gyrification } \\
\text { Other: renal angiomyolipoma }\end{array}$ \\
\hline 11 & $f$ & 1.7 & 30 & $\mathrm{TSC2}$ & sporadic & $C R$ & $C R$ & Neuro: Epilepsy, tubers, SEN, DD \\
\hline 12 & $\mathrm{~m}$ & 2.1 & 0 & TSC2 & sporadic & SEGA & SEGA & $\begin{array}{l}\text { Neuro: Epilepsy, tubers, SEN, white } \\
\text { matter lesions, DD } \\
\text { Cardiac: CR }\end{array}$ \\
\hline 13 & $\mathrm{~m}$ & 2.6 & 15 & $\mathrm{TSC2}$ & sporadic & $C R$ & $C R$ & $\begin{array}{l}\text { Skin: white spots } \\
\text { Neuro: tubers, SEN, DD }\end{array}$ \\
\hline 14 & $\mathrm{~m}$ & 3.3 & prenatal & TSC 2 & sporadic & $C R$ & $C R$ & $\begin{array}{l}\text { Skin: white spots, angiofibromas } \\
\text { Neuro: Epilepsy, SEN, DD }\end{array}$ \\
\hline 15 & $\mathrm{~m}$ & 0.9 & prenatal & $\mathrm{TSCl}$ & sporadic & $C R$ & $C R$ & None \\
\hline 16 & $\mathrm{~m}$ & 0.3 & 90 & $\mathrm{TSC2}$ & sporadic & Epilepsy & Epilepsy & $\begin{array}{l}\text { Neuro: tubers, SEN, DD } \\
\text { Cardiac: CR } \\
\text { Other: retinal hamartomas, renal } \\
\text { angiomyolipoma }\end{array}$ \\
\hline 17 & $\mathrm{~m}$ & 2.4 & 30 & None & sporadic & $C R$ & Epilepsy & $\begin{array}{l}\text { Skin: white spots } \\
\text { Neuro: tubers, SEN, DD }\end{array}$ \\
\hline
\end{tabular}

CR cardiac rhabdomyoma, DD developmental delay, NA not available, SEGA subependymal giant cell astrocytoma, SEN subependymal nodule

epilepsy in 4 cases $(23.5 \%)$ and congenital focal lymphedema in 1 case $(5.9 \%)$ (Table 1 , Fig. 1$)$.

In all subjects everolimus (Certican ${ }^{\mathrm{TM}}$, Votubia $^{\mathrm{T \mu}}$ ) was used as mTOR inhibitor. Everolimus was administered orally in all cases. Therapy was conducted with a median age at initiation of 5 months (range 0-19 months).

\section{Safety profile of everolimus therapy}

Data on the safety profile of everolimus therapy are summarized in Table 2. Dosing regimens and absolute dosages varied significantly between centers. In general, newborns up to 3 months received everolimus in doses ranging from $0.05-0.3 \mathrm{mg}$ daily, while infants older than 5 months received higher doses ranging from 1 to $5 \mathrm{mg}$ daily.

Adverse events were classified according to the Common Terminology Criteria of Adverse Events (CTCAE, Version 5.0 [14]). Grade 1-2 adverse events occurred in 12 cases with a median of 1 adverse event (range $0-5$ ) per individual and included mild transient stomatitis (2 


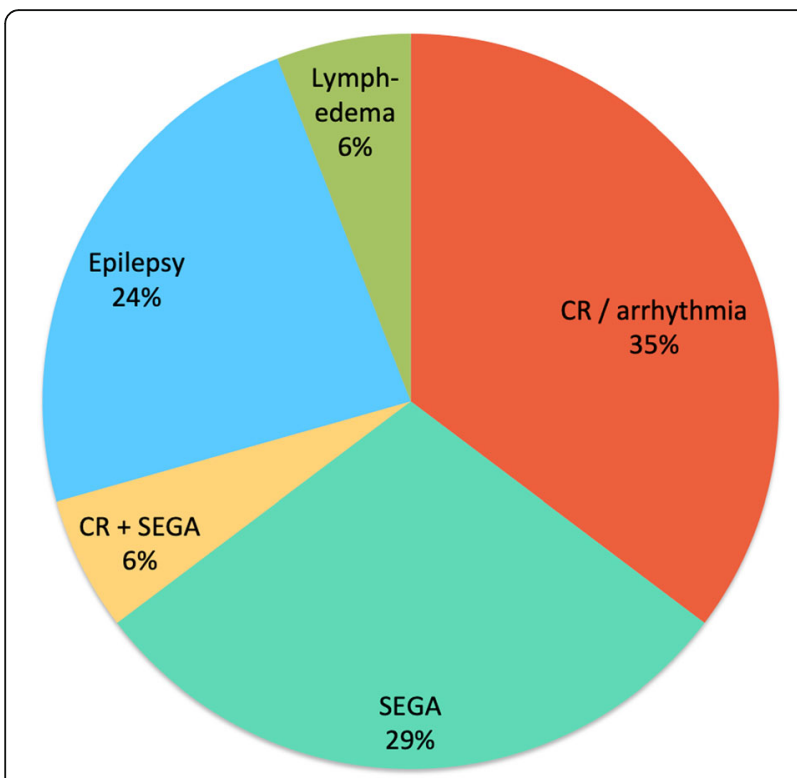

Fig. 1 Reasons for initiation of mTOR inhibitor treatment. $C R$ cardiac rhabdomyoma. SEGA subependymal giant cell astrocytoma.

cases), worsening of infantile acne (1 case), increase of serum cholesterol and triglycerides (4 cases), changes in serum phosphate levels ( 2 cases), increase of cholinesterase ( 2 cases), increase of serum lactate dehydrogenase (1 case), transient neutropenia ( 2 cases), transient anemia (1 case), transient lymphopenia ( 1 case) and recurrent infections (7 cases) (Fig. 2). No grade 3-4 adverse events were reported. Treatment is currently ongoing in 13 of 17 patients. Everolimus treatment was discontinued due to rapid shrinkage of a cardiac rhabdomyoma after 19 days of treatment without rebound tumor growth within a 5 month follow-up period in patient \#14 [13], because of stable disease after significant reduction of a SEGA in patient \#12, presurgically before removal of an epileptogenic tuber in patient \#16, and due to lack of improvement of seizures in patient \#17.

Comedications during everolimus therapy included vigabatrin, valproate, levetiracetam, oxcarbazepine, topiramate, lamotrigine, sultiame, phenobarbital, ACTH, propranolol, flecainide, metoprolol, amiodarone, metildigoxin, propafenone, sotalol, trimethoprim, ketogenic diet and modified Atkins diet. In one girl (patient \#7) a decrease in trough levels of oxcarbazepine was observed after initiation of everolimus. No other relevant interactions with everolimus treatment were reported.

Routine check-ups were performed in 2 monthly to yearly intervals and included routine laboratory work-up with complete blood count, liver and kidney studies, serum triglycerides and cholesterol as well as drug trough levels, EEG studies and cardiac and neurologic imaging.
Vaccination status and social integration of children before and during everolimus therapy were assessed where data were available (Table 2). In 5/17 children vaccination status was completed in accordance to official recommendations before initiation of everolimus treatment. During treatment live vaccines were avoided in 6 patients. In one child vaccinations were performed during a treatment pause of 3 months (patient \#10). In two patients, who were treated with everolimus in the neonatal period, vaccinations including live vaccines were conducted according to official recommendations despite everolimus treatment (patient \#9 and \#11). No vaccination related adverse events were reported.

\section{Changes of cardiac manifestations and SEGA size under everolimus therapy}

Sixteen of 17 patients (94.1\%) showed cardiac rhabdomyomas at birth. In 7 of these 16 cases (43.8\%) everolimus was initiated due to obstruction of cardiac outflow or cardiac arrhythmias. In all of these 7 cases, and in one additional case treated for SEGA (patient \#12), rhabdomyomas decreased in size under everolimus therapy (Table 3). In one case (patient \#13) cardiac arrhythmias had been refractory to treatment with flecainide, metoprolol, amiodarone and metildigoxin. Initiation of everolimus therapy at 3 months of age led to rapid decrease of associated rhabdomyoma size and therapeutic control of cardiac arrhythmias within 1 month. Discontinuation of treatment in the presence of stable disease at 4 months of age however caused regrowth of the cardiac rhabdomyoma and recurrence of the arrhythmias warranting restart of everolimus therapy with again rapid normalization of the cardiac rhythm pattern. A second attempt to withdraw everolimus during the second year of life again led to recurrence of arrhythmias, barely controllable under quadruple anti-arrhythmic therapy. Addition of everolimus again alleviated disease severity.

Seven of 17 patients (41.2\%) developed SEGA during the observation period. In 6/7 patients everolimus was started due to growing or symptomatic SEGA. In 5 of these 6 patients $(83.3 \%)$ SEGA size decreased significantly during therapy, while in 1 patient (patient \#8) no effect was observed (Table 3, Fig. 4). Among the patients treated for SEGA, 2 patients (patient \#9 and \#12) were treated within the first month of life. A significant reduction of SEGA size was documented on short time follow-up MRI after 2 and 3 months of treatment respectively.

\section{Epilepsy and neurodevelopment under everolimus therapy}

Epilepsy was diagnosed in 14/17 patients (82.4\%) during their first 2 years of life. In 4/17 (23.5\%) everolimus treatment was started for treatment-resistant epilepsy (Table 3). One patient (patient \#5) showed marked 
Table 2 Safety profile of mTOR inhibitor therapy

\begin{tabular}{|c|c|c|c|c|c|c|}
\hline $\begin{array}{l}\text { Patient } \\
\#\end{array}$ & $\begin{array}{l}\text { Age at start of } \\
\text { treatment }\end{array}$ & Dosages & Comedications & $\mathrm{AE}$ & $\begin{array}{l}\text { Vaccination status } \\
\text { before therapy }\end{array}$ & $\begin{array}{l}\text { Vaccination status } \\
\text { during therapy }\end{array}$ \\
\hline 1 & 19 months & $\begin{array}{l}2.5 \mathrm{mg} \\
\text { once daily }\end{array}$ & VGB, MAD & $\begin{array}{l}\text { Recurrent URTI / LRTI } \\
\text { Increase of cholesterol / TG }\end{array}$ & Complete & NA \\
\hline 2 & 14 months & $\begin{array}{l}2.5 \mathrm{mg} 3 \\
\text { times per week }\end{array}$ & VGB, STM, VPA & None & Complete & No live vaccines \\
\hline 3 & 15 months & $\begin{array}{l}2.5 \mathrm{mg} \\
\text { once daily }\end{array}$ & LTG, VGB & Transient stomatitis & Complete & NA \\
\hline 4 & 17 months & $\begin{array}{l}2 \mathrm{mg} \\
\text { once daily }\end{array}$ & LEV, VPA & Transient stomatitis & Complete & NA \\
\hline 5 & 12 months & $\begin{array}{l}3 \mathrm{mg} \\
\text { once daily }\end{array}$ & OXC & None & NA & No live vaccines \\
\hline 6 & 14 days & $\begin{array}{l}0.3 \mathrm{mg} \text { two } \\
\text { times per week }\end{array}$ & flecainide, propranolol & None & Incomplete & NA \\
\hline 7 & 5 months & 1 mg daily & ACTH, OXC, VGB, TMP & Transient anemia & No vaccinations & NA \\
\hline 8 & 14 months & $2.5 \mathrm{mg}$ daily & different AEDs, TMP & $\begin{array}{l}\text { Recurrent URTI / LRTI } \\
\text { Increase of cholesterol / TG }\end{array}$ & Complete & NA \\
\hline 9 & 7 days & NA & $\begin{array}{l}\text { TPM, VGB, VPA, } \\
\text { propanolol, melatonin }\end{array}$ & $\begin{array}{l}\text { Recurrent infections } \\
\text { Reduction of phosphate } \\
\text { Increase of cholinesterase } \\
\text { Increase of TG } \\
\text { Increase of LDH }\end{array}$ & NA & $\begin{array}{l}\text { Vaccinations under } \\
\text { therapy }\end{array}$ \\
\hline 10 & 2 months & NA & LEV, VGB, sotalol & Recurrent infections & NA & $\begin{array}{l}\text { Vaccinations during } 3 \\
\text { months pause of therapy }\end{array}$ \\
\hline 11 & 7 days & $\begin{array}{l}0.05 \mathrm{mg} \text { every } \\
\text { other day }\end{array}$ & $\begin{array}{l}\text { VPA, VGB, TPM, } \\
\text { propranolol, propafenone }\end{array}$ & $\begin{array}{l}\text { Worsening of infantile } \\
\text { acne } \\
\text { Increase of phosphate } \\
\text { Increase of cholinesterase }\end{array}$ & NA & $\begin{array}{l}\text { Vaccinations under } \\
\text { therapy }\end{array}$ \\
\hline 12 & 1 month & $\begin{array}{l}0.03 \mathrm{mg} / \mathrm{m}^{2} \\
\text { twice per day }\end{array}$ & LEV, VGB & $\begin{array}{l}\text { Transient neutropenia } \\
\text { UTI }\end{array}$ & NA & NA \\
\hline 13 & 3 months & $\begin{array}{l}0.1 \mathrm{mg} \text { twice } \\
\text { per day }\end{array}$ & $\begin{array}{l}\text { VGB, flecainide, metoprolol, } \\
\text { amiodarone, metildigoxin }\end{array}$ & $\begin{array}{l}\text { Transient neutropenia } \\
\text { Recurrent URTI }\end{array}$ & NA & NA \\
\hline 14 & 2 days & $\begin{array}{l}1.5-2 \mathrm{mg} / \mathrm{m}^{2} \\
\text { daily }\end{array}$ & $\begin{array}{l}\text { VGB, LEV, digoxin, TMP/SMX, } \\
\text { nystatin }\end{array}$ & $\begin{array}{l}\text { Increase of cholesterol / TG } \\
\text { Transient lymphopenia }\end{array}$ & NA & No live vaccines \\
\hline 15 & 2 days & $0.25 \mathrm{mg}$ daily & TMP/SMX, nystatin & None & NA & No live vaccines \\
\hline 16 & 7 months & $\begin{array}{l}0.5 \mathrm{mg} \text { twice } \\
\text { per day }\end{array}$ & $P B, V G B$ & Recurrent infections & NA & No live vaccines \\
\hline 17 & 10 months & 5 mg daily & OXC, VGB, KD & None & NA & No live vaccines \\
\hline
\end{tabular}

$A C T H$ adrenocorticotropic hormone, $A E$ adverse event, $C R$ cardiac rhabdomyoma, $D D$ developmental delay, $K D$ ketogenic diet, $L D H$ lactate dehydrogenase, $L E V$ levetiracetam, $L R T I$ lower respiratory tract infection, $L T G$ lamotrigine, MAD modified Atkins diet, NA not available, OXC oxcarbazepine, $P B$ phenobarbital, SEGA subependymal giant cell astrocytoma, SEN subependymal nodule, SMX sulfamethoxazole, STM sulthiame, TG triglycerides, TMP trimethoprim, TPM topiramate, URTI upper respiratory tract infection, UTI urinary tract infection, VGB vigabatrin, VPA valproic acid

improvement and became almost free of seizures on combination therapy with everolimus and oxcarbazepine. The second patient (patient \#10) was highly refractory to anticonvulsants including levetiracetam, oxcarbazepine, sultiame, vigabatrin, pregabalin, pheytoin, pyridoxine and corticosteroids. He had epilepsy surgery with removal of a cortical tuber and was started on everolimus. However, despite a combination of vigabatrin, levetiracetam and everolimus, he still suffers from daily seizures. Similarly, the third patient (patient \#17), experiencing refractory seizures under levetiracetam, oxcarbazepine, vigabatrin, ketogenic diet and everolimus, underwent epilepsy surgery, which only led to short-term seizure freedom. The fourth patient (patient \#16), by contrast, previously experiencing refractory focal seizures under levetiracetam, vigabatrin, phenobarbital and ketogenic diet, showed 50\% reduction of seizure frequency after start of everolimus and was seizure free under temporary toxic everolimus trough levels of $97.4 \mathrm{ng} / \mathrm{ml}$. On reduction of everolimus to non-toxic levels of $14-18 \mathrm{ng} / \mathrm{ml}$ seizures recurred. Finally the patient underwent epilepsy surgery and is currently free of seizures. 


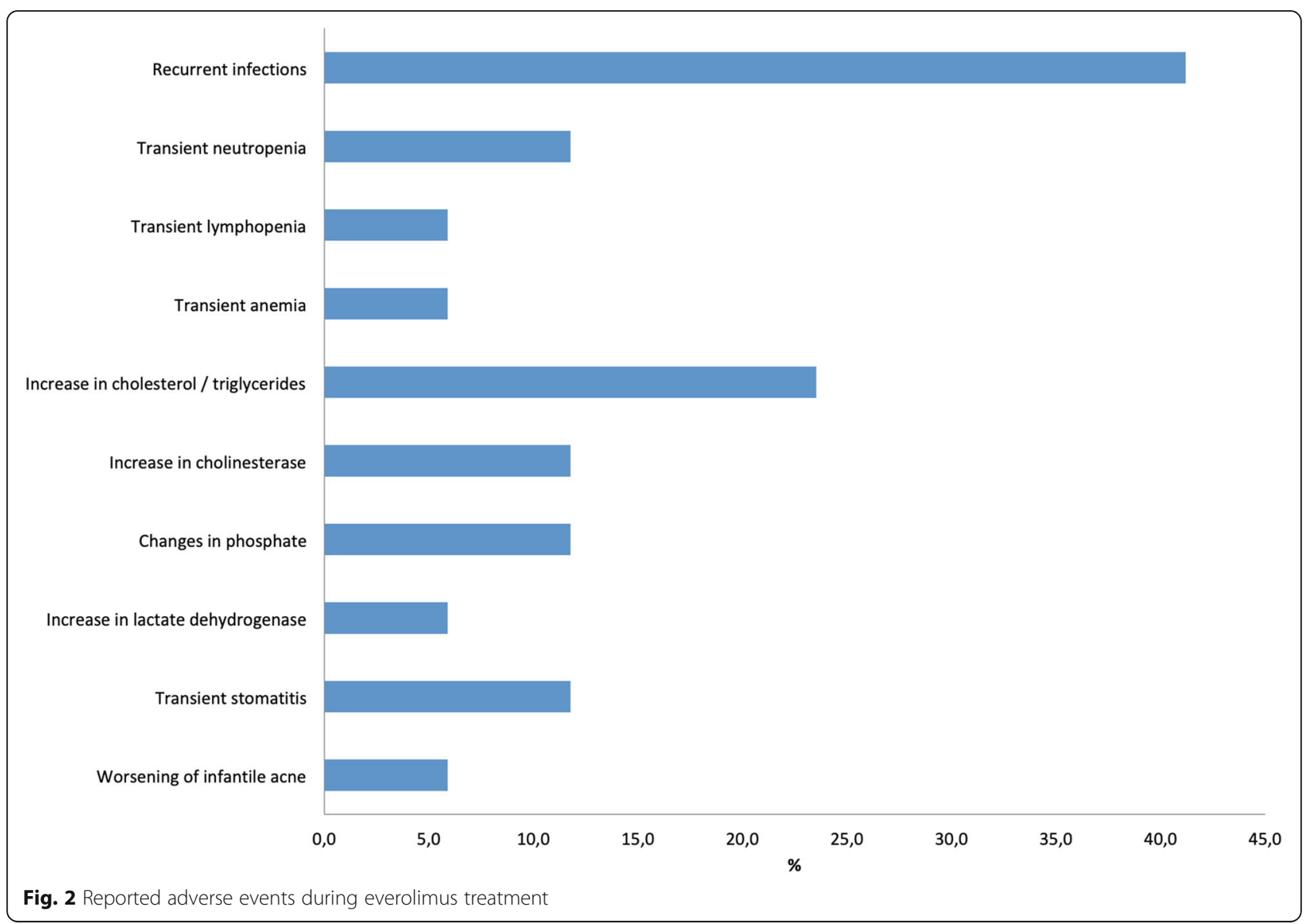

Seven of 17 patients (41.2\%) developed IS during the observation period (Table 4). IS occurred at a median age of 5.5 months (range 1-7 months). Primary treatments included ACTH $(n=1)$ or vigabatrin $(n=7)$. In 5 cases cessation of spasms occurred after a median duration of 3 months. No data were available for the remaining 2 cases. Eight of 17 patients received everolimus treatment within the neonatal period (first 3 months of life) prior to the vulnerable period for IS. The remaining 9 patients were started on everolimus treatment after 5 months of age. IS occurred in both groups. Three of 8 patients (37.5\%) in the neonatal group developed IS while $4 / 9$ patients (44.4\%) in the group of older children were affected. Neurodevelopment was abnormal in both groups on follow-up (Table 4).

Neurodevelopment prior to initiation of everolimus treatment was evaluated in 14/17 children (Table 3). Due to the lack of valid scoring systems in very young children, developmental assessment was mostly carried out by pediatricians and rated based on clinical exam and the achievement of age-expected psychomotor milestones. While in 5 cases (35.7\%) development was reported as normal (patients \#1, \#6, \#7, \#12 and \#15), 9 patients (64.3\%) showed various degrees of developmental delay. Reported findings included delays in the acquisition of a social smile, delayed achievement of speech or motor milestones (mostly unsupported sitting) and the presence of muscular hypotonia or focal neurologic deficits. On follow-up, 15 patients were tested (Table 3). Data on structural assessments were available in 8 cases and included Bayley II, K-ABC (Kaufman Assessment Battery for Children), WPPSI-III (Wechsler Preschool and Primary Scale of Intelligence), SON-R (Snijders-Oomen non-verbal intelligence test), MFED (Münchener Funktionelle Entwicklungsdiagnostik), VABS II (Vineland Adaptive Behavior Scale), CBCL 1 1/2-5 (Child Behavior Checklist), ELFRA-2 (Elternfragebogen für die Früherkennung von Risikokindern) and GMDS (Griffith Mental Developmental Scales) testing. Three patients (20\%) had normal results (patients \#3, \#6 and 10), while $12(80 \%)$ showed a wide spectrum of developmental delay ranging from mild motor or speech delay to global developmental delay. Interestingly, one patient (patient \#2), reported with severe global developmental delay on initial testing, showed significant neurodevelopmental improvement after the start of everolimus at the age of 14 months. 
Table 3 Effect of mTOR inhibitor therapy on TSC-related manifestations and neurodevelopment

\begin{tabular}{|c|c|c|c|c|}
\hline Patient \# & Reason for therapy & Effect of therapy & $\begin{array}{l}\text { Development before } \\
\text { therapy }\end{array}$ & Development at follow-up \\
\hline 1 & SEGA & Decrease of SEGA & Normal & DD (not specified) \\
\hline 2 & Congenital focal lymphedema & $\begin{array}{l}\text { Regression of congenital focal } \\
\text { lymphedema }\end{array}$ & DD (global) & $\begin{array}{l}\text { DD (not specified) } \\
K-A B C, \text { WPPSI-III }\end{array}$ \\
\hline 3 & SEGA & Decrease of SEGA & $\mathrm{DD}$ (motor) & $\begin{array}{l}\text { Normal } \\
\text { SON-R }\end{array}$ \\
\hline 4 & SEGA & Decrease of SEGA & DD (not specified) & $\begin{array}{l}\text { DD (global) } \\
\text { MFED }\end{array}$ \\
\hline 5 & Epilepsy & Decrease of seizure frequency & DD (not specified) & NA \\
\hline 6 & $C R$ & Decrease of $C R$ & Normal & Normal \\
\hline 7 & $C R$ & Decrease of CR & Normal & $\begin{array}{l}\text { DD (speech) } \\
\text { MFED }\end{array}$ \\
\hline 8 & SEGA & No effect & DD (not specified) & $\begin{array}{l}\text { DD (global) } \\
\text { Bayley II }\end{array}$ \\
\hline 9 & $\mathrm{CR} / \mathrm{SEGA}$ & Decrease of CR / SEGA & NA & DD (global) \\
\hline 10 & Epilepsy & Ongoing seizures & NA & Normal \\
\hline 11 & CR / cardiac arrhythmia & Decrease of $C R$ & NA & DD (global) \\
\hline 12 & SEGA & Decrease of CR / SEGA & Normal & $\begin{array}{l}\text { DD (global) } \\
\text { Bayley II }\end{array}$ \\
\hline 13 & CR / cardiac arrhythmia & Decrease of $C R$ & $\mathrm{DD}$ (motor) & $\begin{array}{l}\text { DD (motor) } \\
\text { Bayley II, VABS II, } \\
\text { CBCL 11/2-5, ELFRA-2 }\end{array}$ \\
\hline 14 & $C R$ & Decrease of $C R$ & DD (global) & $\mathrm{DD}$ (motor) \\
\hline 15 & $C R$ & Decrease of CR & Normal & NA \\
\hline 16 & Epilepsy & Decrease of seizure frequency & DD (not specified) & $\begin{array}{l}\text { DD (global) } \\
\text { Bayley II, GMDS }\end{array}$ \\
\hline 17 & Epilepsy & Ongoing seizures & $\mathrm{DD}$ (motor) & DD (not specified) \\
\hline
\end{tabular}

CBCL Child Behavior Checklist, CR cardiac rhabdomyoma, DD developmental delay, ELFRA Elternfragebogen für die Früherkennung von Risikokindern, GMDS Griffith Mental Developmental Scales, K-ABC Kaufman Assessment Battery for Children, MFED Münchener Funktionelle Entwicklungsdiagnostik, NA not available, SEGA subependymal giant cell astrocytoma, SON-R Snijders-Oomen non-verbal intelligence test, VABS Vineland Adaptive Behavior Scale, WPPSI Wechsler Preschool and Primary Scale of Intelligence

\section{Discussion}

We collected data from 17 TSC patients from 12 referring centers in Germany. All of these children received everolimus therapy in the first 2 years of life. Treatment was mainly initiated for symptomatic cardiac rhabdomyomas (35.3\%), SEGA (29.4\%) or the combination of both $(5.9 \%)$. Other reasons for mTOR inhibition were refractory epilepsy $(23.5 \%)$ and one rare case of congenital focal lymphedema of the leg (5.9\%).

\section{Safety profile}

Everolimus was the only mTOR inhibitor used in our study. Everolimus therapy was overall well tolerated

Table 4 Effect of mTOR inhibitor therapy on IS and neurodevelopment

\begin{tabular}{|c|c|c|c|c|c|c|}
\hline $\begin{array}{l}\text { Patient } \\
\#\end{array}$ & $\begin{array}{l}\text { Age at start of } \\
\text { mTOR inhibitor }\end{array}$ & $\begin{array}{l}\text { AAO of } \\
\text { IS }\end{array}$ & $\begin{array}{l}\text { Previous } \\
\text { treatment }\end{array}$ & $\begin{array}{l}\text { Time to cessation } \\
\text { of IS }\end{array}$ & $\begin{array}{l}\text { Development prior to start } \\
\text { of mTOR inhibition }\end{array}$ & $\begin{array}{l}\text { Development during } \\
\text { follow-up }\end{array}$ \\
\hline 1 & 19 months & 7 months & VGB & 16 months & Normal & DD (not specified) \\
\hline 2 & 14 months & 5 months & VGB & 3 months & DD (global) & DD (not specified) \\
\hline 3 & 15 months & 6 months & VGB & NA & DD (motor) & Normal \\
\hline 7 & 5 months & NA & ACTH, VGB & 1 month & Normal & DD (speech) \\
\hline 9 & 7 days & 7 months & VGB & 4 months & NA & DD (global) \\
\hline 11 & 7 days & 1 month & VGB & NA & NA & DD (global) \\
\hline 12 & 1 day & 5 months & VGB & 1 month & NA & DD (global) \\
\hline
\end{tabular}


(Table 2). Grade 1-2 adverse events occurred in $70.6 \%$ of patients and included dermatologic manifestations (mild transient stomatitis, worsening of infantile acne), subclinical laboratory changes (increase of cholesterol and triglycerides, changes in phosphate levels, increase of cholinesterase and lactate dehydrogenase, transient anemia and neutropenia) as well as uncomplicated infections. During winter and under high everolimus trough levels, one patient (patient \#1) showed recurrent viral respiratory tract infections, repeatedly complicated by bacterial superinfection requiring antibiotic therapy. No grade 3-4 adverse events were reported. Routine laboratory checks, in most cases monthly blood tests, proved as helpful.

Treatment is currently ongoing in $76.5 \%$ and in the remaining $23.5 \%$ was discontinued due to stable disease with reduced SEGA volume in one case (patient \#12), reduction in cardiac rhabdomyoma size in one child (patient \#14 [13]), before epilepsy surgery in another patient (patient \#16) and due to refractory seizures despite treatment in the last patient (patient \#17).

In most patients vaccinations with live-attenuated vaccines were not performed or in one case only in the context of a treatment pause of 3 months (patients \#10). In 2 cases vaccinations including live-attenuated vaccinations were performed despite everolimus treatment and without adverse events. No data regarding immune response during vaccinations with everolimus were available. However, in the elder population everolimus treatment has been previously reported as safe and helpful to induce an immune response [15].

\section{Dosing}

Dosing regimens and absolute doses of everolimus varied significantly and ranged from $0.05-0.3 \mathrm{mg}$ daily in neonates to $1-5 \mathrm{mg}$ daily in children older than 5 months. No specific dosing recommendations for everolimus are available for neonates so far, however, previous studies have shown that the primary elimination pathway of everolimus, i.e. the CYP3A4 pathway, is extremely weak or absent in neonates, highlighting the need for cautious use and repetitive drug monitoring $[16,17]$. Along these lines two patients in our study showed toxic everolimus trough levels of around $100 \mathrm{ng} /$ $\mathrm{ml}$ after an initial dose of $0.4-0.45 \mathrm{mg}\left(=1.5-2 \mathrm{mg} / \mathrm{m}^{2}\right)$ [13] and under a dose of $2 \mathrm{mg}$ twice daily $(=0,4 \mathrm{mg} / \mathrm{kg})$ (patient \#16) respectively.

We searched the literature for reported cases of everolimus treatment in neonates (Table 5). All reported neonates were treated for cardiac rhabdomyomas. The median dose was $0.64 \mathrm{mg} / \mathrm{m}^{2} /$ day (range $0.12-1.0 \mathrm{mg}$ / $\mathrm{m}^{2} /$ day), targeting median trough levels of $10.2 \mathrm{ng} / \mathrm{ml}$ (range $4.5-13.7 \mathrm{ng} / \mathrm{ml}$ ). This dose is significantly lower than recommended doses in children above 3 years of age $\left(3.0 \mathrm{mg} / \mathrm{m}^{2} /\right.$ day $)$ for SEGA treatment $[18,19]$.

\section{Outcomes}

Therapeutic benefits following everolimus treatment were present in more than $80 \%$ of patients (Fig. 3) and included decrease of cardiac rhabdomyoma size and reduction of arrhythmias (8/8), decrease of SEGA size $(5 / 6)$, regression of congenital focal lymphedema (1/1) and reduction of seizure frequency $(2 / 4)$. Neither patient $\# 8$, treated for SEGA, nor patients \#10 and \#17, treated for highly refractory epilepsy, showed improvement under everolimus.

\section{Cardiac manifestations}

Cardiac rhabdomyoma size rapidly decreased in all patients treated with everolimus. Of special interest is the case of patient \#13. In this child discontinuation of everolimus therapy after sustained reduction of a cardiac rhabdomyoma repeatedly led to a regrowth and recurrence of potentially life-threatening arrhythmias warranting restart of everolimus, again resulting in prompt control of the arrhythmias that could not be achieved by anti-arrhythmic medication alone. This observation applies for beneficial effects of mTOR inhibition also on the excitability of electrically active cardiomyocytes in TSC-related arrhythmias comparable to its anticonvulsant effects in neurons. In $85.7 \%$ of patients treated for cardiac rhabdomyomas, everolimus was started within the first 3 months of life. These findings are in line with several reports and small case series in the literature similarly demonstrating relevant cardiac rhabdomyoma size reduction in neonates with high-risk for cardiac surgery, treated with everolimus [13, 20-31]. Our series confirms that neonatal everolimus treatment is overall well tolerated and beneficial for those infants even for prolonged treatment.

\section{Sega}

SEGA size reduced significantly in the majority (83.3\%) of patients (Table 3 ). No patient required surgical removal of SEGA during the study period. Two patients with SEGA received everolimus in the neonatal period (patients \# 9 and \#12) with beneficial effects on tumor size (Fig. 4). Data on SEGA treatment in children below 2 years of age are still scarce. Kuki and colleagues successfully used everolimus in 5 children under the age of 12 months and reported rapid SEGA volume reduction of at least $50 \%$ in all treated patients within 6 months [32]. Everolimus is currently widely used and approved for the early treatment of SEGA. Our study provides further evidence for the safety and beneficial effects of 
Table 5 Summary of previous reports on mTOR inhibitor dosing in neonates

\begin{tabular}{|c|c|c|c|c|c|c|c|c|}
\hline $\begin{array}{l}\text { mTOR } \\
\text { inhibitor }\end{array}$ & $\begin{array}{l}\text { AAO of } \\
\text { mTOR inhibitor }\end{array}$ & $\begin{array}{l}\text { Dosing } \\
\text { regimen }\end{array}$ & $\begin{array}{l}\text { Dose } \\
{[\mathrm{mg} / \mathrm{m} 2 / \mathrm{d}]}\end{array}$ & $\begin{array}{l}\text { Trough } \\
\text { levels [ng/ml] }\end{array}$ & Duration & $\mathrm{AE}$ & Prophylaxis & Reference \\
\hline$\overline{E V E}$ & NA & $\begin{array}{l}0.25 \mathrm{mg} \\
\text { twice per day } \\
2 \text { days } \\
\text { per week }\end{array}$ & NA & $5-15$ & $\begin{array}{l}2.5 \\
\text { months }\end{array}$ & $\begin{array}{l}\text { Increase of TG } \\
\text { Self-limiting diarrhea } \\
\text { Decreased CD/CD8 ratio } \\
\text { lymphopenia }\end{array}$ & TMP/SMX & $\begin{array}{l}\text { (Demir et } \\
\text { al. 2012) }\end{array}$ \\
\hline Sirolimus & 10 days & 0.4 mg daily & NA & NA & 24 days & Increase of TG & TMP/SMX & $\begin{array}{l}\text { (Breathnach } \\
\text { et al. 2014) }\end{array}$ \\
\hline EVE & 20 days & $0.1 \mathrm{mg}$ daily & 0.64 & 11 & 34 days & Transient hypokalemia & NA & $\begin{array}{l}\text { (Mohamed et } \\
\text { al. 2014) }\end{array}$ \\
\hline EVE & 2 days & $\begin{array}{l}0.25 \text { mg twice } \\
\text { per day } \\
2 \text { days } \\
\text { per week }\end{array}$ & NA & $3.6-7.8$ & $\begin{array}{l}3 \\
\text { months }\end{array}$ & NA & NA & $\begin{array}{l}\text { (Dogan et } \\
\text { al. 2015) }\end{array}$ \\
\hline EVE & 4 days & $0.1 \mathrm{mg}$ daily & 0.64 & 11.5 & 42 days & NA & NA & \multirow{2}{*}{$\begin{array}{l}\text { (Goyer et } \\
\text { al. 2015) }\end{array}$} \\
\hline EVE & 9 days & $0.1 \mathrm{mg}$ daily & 0.64 & 10.2 & NA & NA & NA & \\
\hline EVE & 21 days & NA & 3 & $4-5$ & NA & Hyponatremia & $\begin{array}{l}\text { antibiotic } \\
\text { prophylaxis }\end{array}$ & $\begin{array}{l}\text { (Mlczoch } \\
\text { et al. 2015) }\end{array}$ \\
\hline EVE & NA & $\begin{array}{l}0.25 \text { mg twice } \\
\text { per day } \\
2 \text { days } \\
\text { per week }\end{array}$ & NA & NA & 4 weeks & NA & NA & $\begin{array}{l}\text { (Oztunc } \\
\text { et al. 2015) }\end{array}$ \\
\hline EVE & 2 days & $\begin{array}{l}0.15-0.2 \mathrm{mg} \\
\text { daily }\end{array}$ & 1 & $10-15$ & 19 days & $\begin{array}{l}\text { Toxic levels of } 108 \mathrm{ng} / \mathrm{ml} \text { under initial } \\
\text { dose of } 0.4-0.45 \mathrm{mg}\left(=1.5-2 \mathrm{mg} / \mathrm{m}^{2}\right)\end{array}$ & NA & $\begin{array}{l}\text { (Wagner } \\
\text { et al. 2015) }\end{array}$ \\
\hline EVE & 7 days & $0.25 \mathrm{mg}$ daily & 1 & NA & $\begin{array}{l}10 \\
\text { weeks }\end{array}$ & $\begin{array}{l}\text { Mild mucositis } \\
\text { Increase of TG }\end{array}$ & NA & $\begin{array}{l}\text { (Colaneri } \\
\text { et al. 2016) }\end{array}$ \\
\hline EVE & NA & $\begin{array}{l}0.25 \mathrm{mg} \text { twice } \\
\text { per day } \\
2 \text { days } \\
\text { per week }\end{array}$ & NA & $5-10$ & NA & NA & NA & $\begin{array}{l}\text { (Emir et } \\
\text { al. 2017) }\end{array}$ \\
\hline EVE & NA & $0.5 \mathrm{mg}$ daily & NA & NA & NA & NA & NA & $\begin{array}{l}\text { (Hoshal et } \\
\text { al. 2016) }\end{array}$ \\
\hline EVE & 20 days & $0.1 \mathrm{mg}$ daily & NA & 13.7 & 34 days & Suspected infection & NA & \multirow{4}{*}{$\begin{array}{l}\text { (Aw et } \\
\text { al. 2017) }\end{array}$} \\
\hline EVE & 4 days & NA & NA & 11 & 42 days & None & NA & \\
\hline EVE & 9 days & $0.1 \mathrm{mg}$ daily & NA & 10.2 & NA & Oral ulcers & NA & \\
\hline EVE & 1 day & $0.1 \mathrm{mg}$ daily & NA & 10.2 & 36 days & None & NA & \\
\hline EVE & NA & $\begin{array}{l}0.03125 \\
\text { mg daily }\end{array}$ & 0.12 & $3-7$ & 2 weeks & $\begin{array}{l}\text { Adenovirus pneumonia } \\
\text { High trough levels of } 20 \mathrm{ng} / \mathrm{ml} \text { under } \\
0.125 \mathrm{mg}\left(0.0558 \mathrm{mg} / \mathrm{m}^{2}\right)\end{array}$ & NA & $\begin{array}{l}\text { (Chang et } \\
\text { al. 2017) }\end{array}$ \\
\hline EVE & NA & NA & 0.35 & 1.81 & NA & NA & NA & \\
\hline EVE & NA & $\begin{array}{l}0.125 \\
\text { mg daily }\end{array}$ & 0.51 & NA & $\mathrm{Na}$ & NA & NA & \\
\hline
\end{tabular}

$A A O$ age at onset, $A E$ adverse events, EVE everolimus, NA not available, TG triglycerides, TMP/SMX trimethoprim/sulfamethoxazole

everolimus therapy for TSC-related SEGA under the age of 2 years.

\section{Other manifestations}

One of our patients presented with congenital focal lymphedema, a very rare presentation of TSC. The frequency of congenital lymphedema in TSC patients has been reported with $0.7 \%$ and only 11 patients have been reported in the literature so far [33-40]. In our patient everolimus treatment showed significant positive effects on tumor texture and mobility of the affected limb (case report under review).

\section{Epilepsy}

Epilepsy is a prevalent feature of TSC and the mTOR pathway plays major roles in epileptogenesis [41]. Unlike classical anticonvulsive drugs targeting ion channels, synaptic receptors or modifying neurotransmitter release, everolimus directly modifies downstream mechanisms involved in TSC-related epileptogenesis. Thus, mTOR inhibition is a tempting approach for TSC-related refractory 


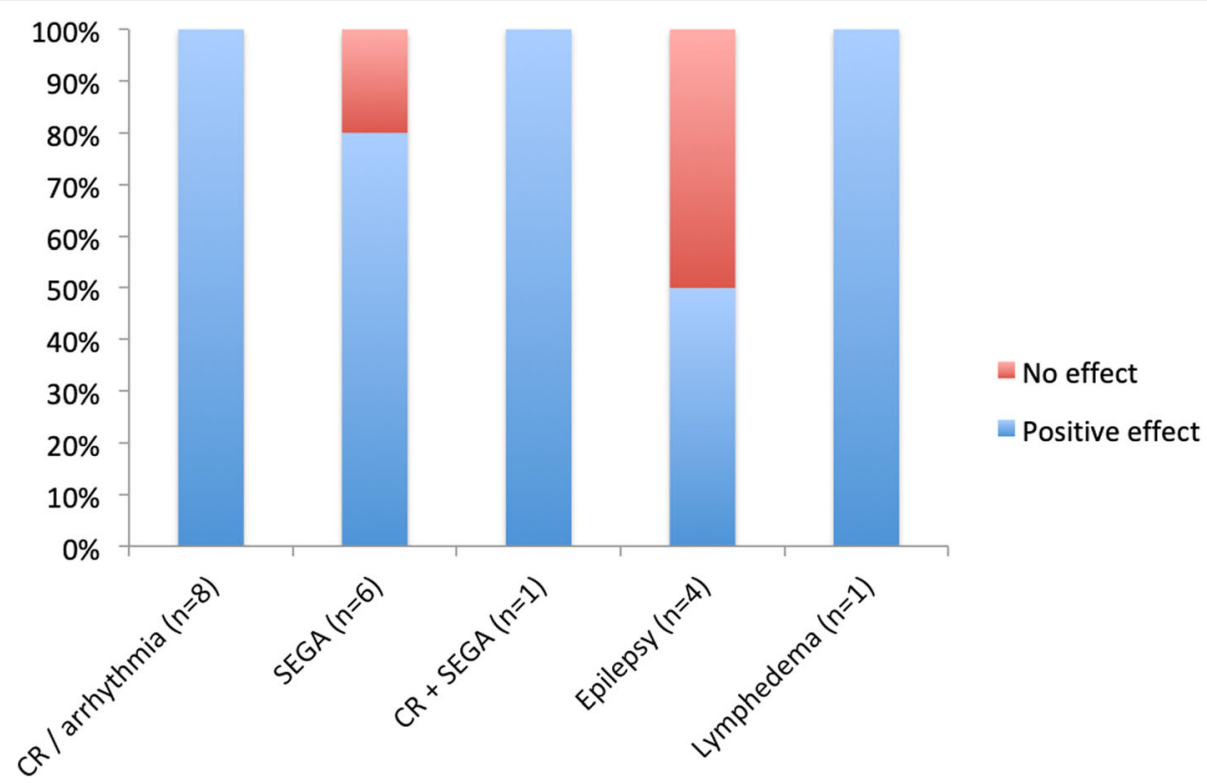

Fig. 3 Effects of everolimus treatment. CR cardiac rhabdomyoma. SEGA subependymal giant cell astrocytoma.

epilepsy, underlined by the results of the EXIST-3 trial that showed sustained reduction of seizure frequency following adjunctive everolimus therapy in TSC-related refractory epilepsy in patients above 2 years [5]. Our cohort is too small to draw definitive conclusions on the benefits of everolimus treatment in TSC-related epilepsy under 2 years of age. More than $80 \%$ of children in our cohort developed seizures. Four were treated with everolimus for refractory epilepsy. While two patients (patients $\# 10$ and \#17) are still suffering from daily seizures despite the use of various antiepileptic regimens, including everolimus and epilepsy surgery, one patient is currently seizure free under combination therapy with everolimus and oxcarbazepine (patient \#6). In the fourth patient (patient \#16) seizure frequency reduced to $50 \%$ under everolimus therapy. Interestingly, trough levels within the toxic range led to temporary seizure freedom, suggesting dosedependent efficacy of everolimus in this child. In our cohort everolimus was effective as adjunctive antiepileptic therapy in 2 of 4 children, corroborating the results of the EXIST-3 trial [5]. Still, further studies are needed to investigate the benefits of mTOR inhibition on TSC-related epilepsy in infancy and early childhood.

\section{Neurodevelopment and infantile spasms}

Neurodevelopment prior to initiation of everolimus treatment was evaluated in $82.4 \%$ of children. While in $35.7 \%$ of these children development was reported as normal, 64.3\% showed psychomotor delay. On followup, $88.2 \%$ of patients were evaluated. $20 \%$ of these had normal results and $80 \%$ of patients showed circumscribed to global developmental delay. Interestingly, one patient (patient \#2) showed significant neurodevelopmental improvement after the start of everolimus at the age of 14 months.

Neurodevelopmental outcome in TSC is closely linked to IS $[6,7]$. The literature on everolimus treatment in TSC-related IS is scarce and only anecdotal reports exist $[10,42]$. Recently, Samueli and colleagues reported improved neurocognitive outcome in 3 of 4 children with TSC-related IS under everolimus treatment. The prevalence of IS in our cohort was $41.2 \%$. Interestingly, IS occurred in $37.5 \%$ of patients treated with everolimus during the first 3 months of life, while $44.4 \%$ of patients with everolimus initiation after 5 months of age developed IS (Table 4). Our patient cohort is currently too small to draw solid conclusions about potential benefits of early everolimus therapy on the occurrence of TSC-related IS and on neurodevelopmental outcome. Further studies are needed to evaluate the prophylactic use of everolimus in the neonatal period regarding IS and neurodevelopment.

\section{Conclusions}

We provide detailed evidence that everolimus treatment is safe and efficacious in TSC patients under the age of 2 years, mostly allowing improved long-term outcome. The treatment was overall well tolerated and adverse events were mild in the great majority of cases. Benefits were reported in most cases including reduction of cardiac rhabdomyomas, improvement of cardiac arrhythmia, shrinkage of SEGA size, regression of congenital focal lymphedema and reduction of seizure frequency. 

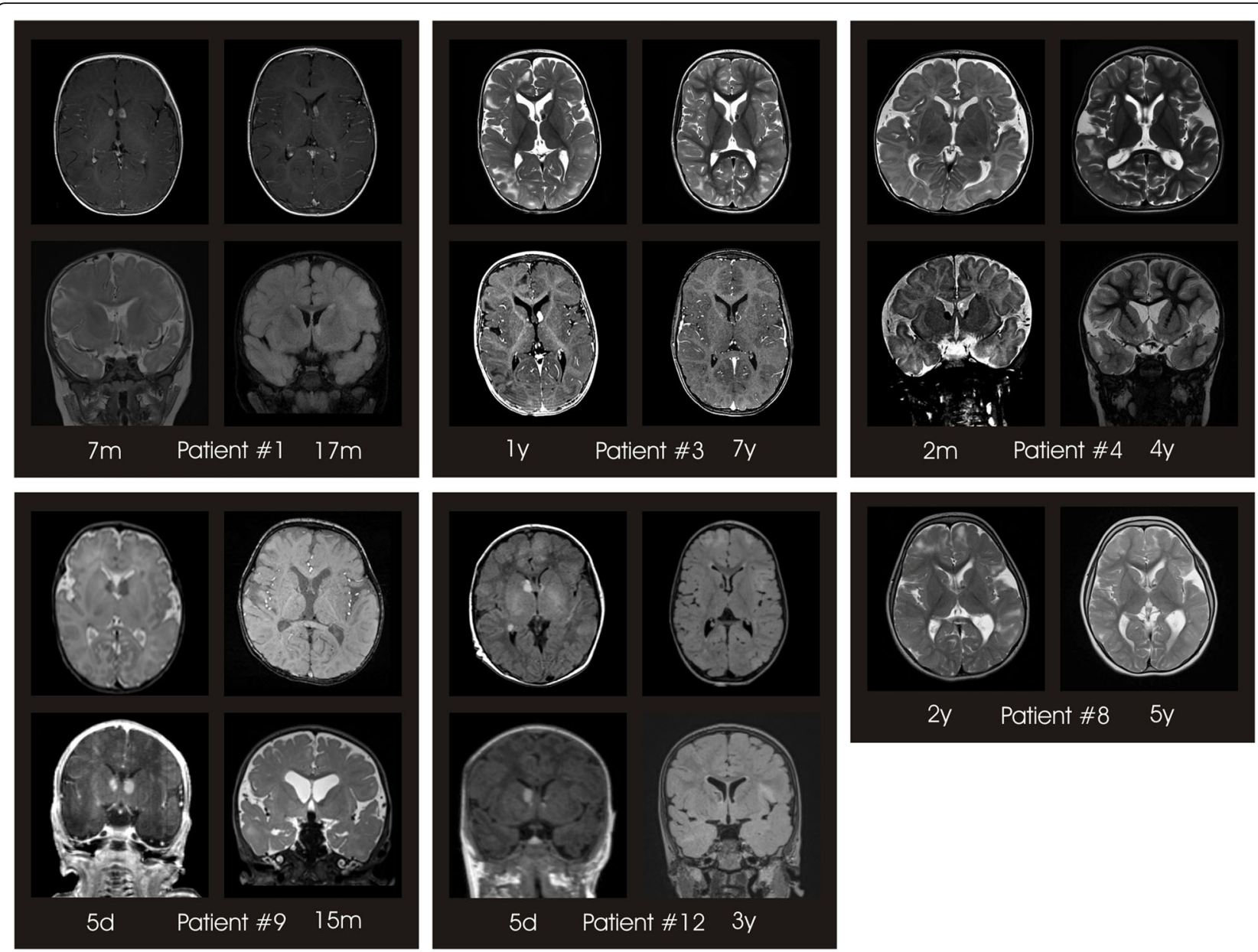

Fig. 4 SEGA development under everolimus treatment. Axial and coronal T2-weighted and T1-weighted with gadolinium MRI sections of 6 patients treated with everolimus for SEGA. All patients were diagnosed with SEGA at risk for development of obstructive hydrocephalus at baseline (left column). On follow-up in 5/6 patients marked reduction of SEGA volume was documented (patient \#1, 3, 4, 9, 12, right column). In patient \#8 SEGA size remained unchanged after initiation of everolimus treatment (right column)

Limitations of this study are a small cohort and the still short follow-up period with a median follow-up of 2.1 years (range $0.5-5.5$ years) since start of everolimus treatment. Thus, no predictions on long-term safety under maintenance therapy can be made. However, so far no overt adverse events have been reported.

Further multicenter studies and registers with larger cohorts and longer follow-up periods will determine the long-term safety of early everolimus therapy in infancy and early childhood and the effects on TSC-related neurodevelopmental disorders.

\section{Methods}

To identify children with TSC and mTOR inhibitor treatment, we contacted all TSC centers in Germany. Seventeen patients from 12 different TSC clinics were identified that fulfilled the inclusion criteria (patient with a definitive diagnosis of TSC according to the 2012 International TSC Consensus Conference [12] and treatment with an mTOR inhibitor started before 2 years of age). Data were collected and rated by one primary investigator per site. All patients and their parents or legal guardians gave informed consent for individual treatment with mTOR inhibitors and sharing of clinical data.

\section{Acknowledgements}

We kindly thank all patients and their families for participating in the study. We further thank the German TSC Centers and Tuberöse Sklerose Deutschland e.V. (TSD e.v) for their support and collaboration. We acknowledge financial support by Deutsche Forschungsgemeinschaft within the funding programme Open Access Publishing, by the BadenWürttemberg Ministry of Science, Research and the Arts and by RuprechtKarls-Universität Heidelberg.

\section{Funding}

The Dietmar Hopp Stiftung provided financial support for this study (Grant 1DH1813319 to Steffen Syrbe)

\section{Availability of data and materials}

All data generated or analysed during this study are included in this published article. 


\section{Authors' contributions}

AS and SS designed the study manuscript and wrote the initial draft. All authors were involved in data acquisition and analysis. All authors read and approved the final manuscript.

\section{Ethics approval and consent to participate}

The study was approved by the local ethics committees of the University of Heidelberg, Germany, and the University of Leipzig, Germany.

\section{Consent for publication}

Not applicable.

\section{Competing interests}

A.S. received grants from Biogen.

I.B. declares that she has no competing interests.

A.W-K. received research funding from Novartis and Nutricia, and honoraria from Novartis, Desitin, Nutricia, Vitaflo and UCB.

B.W. declares that he has no competing interests.

P.K. declares that she has no competing interests.

A.H. declares that he has no competing interests.

M.K.B. received honoraria from PTC Therapeutics.

C.V.T. participated at advisory boards of Novartis and Bayer Vital GmbH.

G.F.H. declares that he has no competing interests.

M.G. declares that he has no competing interests.

S.H. declares that he has no competing interests.

O.K. reports honoraria from Novartis.

S.K. declares that he has no competing interests.

O.W. declares that he has no competing interests.

A.Me. declares that he has no competing interests.

A.M. declares that he has no competing interests.

T.R. declares that he has no competing interests.

J.U.S. declares that he has no competing interests.

A.Se. declares that she has no competing interests.

J.S. declares that she has no competing interests.

T.M. declares that he has no competing interests.

A.Z. declares that he has no competing interests.

S.S. received one travel grant from Novartis.

\section{Publisher's Note}

Springer Nature remains neutral with regard to jurisdictional claims in published maps and institutional affiliations.

\section{Author details}

${ }^{1}$ Division of Child Neurology and Metabolic Medicine, Center for Paediatrics and Adolescent Medicine, University Hospital Heidelberg, Heidelberg, Germany. ${ }^{2}$ Clinic for Children and Adolescents, Epilepsy Centre Kork, Kehl-Kork, Germany. '3Department of Pediatric Neurology, Kassel Hospital, Kassel, Germany. ${ }^{4}$ Department of Child Neurology, University Hospital, Gießen, Germany. ${ }^{5}$ Department of Neuropediatrics, University Hospital of Children, Leipzig, Germany. ${ }^{6}$ Hopp Children's Cancer Center Heidelberg (KiTZ), Heidelberg, Germany. ${ }^{7}$ Clinical Cooperation Unit Pediatric Oncology, German Cancer Research Center (DKFZ) and German Consortium for Translational Cancer Research (DKTK), Heidelberg, Germany. ${ }^{8}$ KiTZ Clinical Trial Unit (ZIPO), Department of Pediatric Hematology and Oncology, Heidelberg University Hospital, Heidelberg, Germany. ${ }^{9}$ Department for Congenital Heart Defects/Paediatric Cardiology, Heidelberg University Hospital, Heidelberg, Germany. ${ }^{10}$ Auf der Bult - Center for Children and Adolescents, Hannover, Germany. ${ }^{11}$ Department of Paediatrics I, Paediatric Neurology, University Hospital Essen, University of Duisburg-Essen, Essen, Germany. ${ }^{12}$ Department of Pediatric Cardiology, University of Leipzig, Heart Center, Leipzig, Germany. ${ }^{13}$ Sana Kliniken Leipziger Land, Borna, Germany. ${ }^{14}$ Department of Paediatric Neurology and Developmental Medicine, Hauner Children's Hospital, University of Munich, Munich, Germany. ${ }^{15}$ Division for Children and Adolescents, Evangelical Hospital Oberhausen, Oberhausen, Germany. ${ }^{16}$ Department of Pediatrics, University Medical Center Schleswig-Holstein, Campus Lübeck, Germany.
Received: 18 January 2019 Accepted: 18 April 2019

Published online: 03 May 2019

\section{References}

1. Crino PB, Nathanson $\mathrm{KL}$, Henske EP. The tuberous sclerosis complex. N Engl J Med. 2006;355(13):1345-56

2. Curatolo P, Moavero R, de Vries PJ. Neurological and neuropsychiatric aspects of tuberous sclerosis complex. Lancet Neurol. 2015;14(7):733-45.

3. Kingswood JC, d'Augeres GB, Belousova E, Ferreira JC, Carter T, Castellana R, et al. TuberOus SClerosis registry to increase disease awareness (TOSCA) baseline data on 2093 patients. Orphanet J Rare Dis. 2017;12(1):2.

4. Krueger DA, Wilfong AA, Holland-Bouley K, Anderson AE, Agricola K, Tudor $C_{\text {, }}$ et al. Everolimus treatment of refractory epilepsy in tuberous sclerosis complex. Ann Neurol. 2013;74(5):679-87.

5. French JA, Lawson JA, Yapici Z, Ikeda H, Polster T, Nabbout R, et al. Adjunctive everolimus therapy for treatment-resistant focal-onset seizures associated with tuberous sclerosis (EXIST-3): a phase 3, randomised, doubleblind, placebo-controlled study. Lancet. 2016;388(10056):2153-63.

6. Chu-Shore CJ, Major P, Camposano S, Muzykewicz D, Thiele EA. The natural history of epilepsy in tuberous sclerosis complex. Epilepsia. 2010;51(7):1236-41.

7. Mettin RR, Merkenschlager A, Bernhard MK, Elix H, Hirsch W, Kiess W, et al. Wide spectrum of clinical manifestations in children with tuberous sclerosis complex--follow-up of 20 children. Brain and Development. 2014;36(4):306-14.

8. Capal JK, Franz DN. Profile of everolimus in the treatment of tuberous sclerosis complex: an evidence-based review of its place in therapy. Neuropsychiatr Dis Treat. 2016;12:2165-72.

9. Hwang SK, Lee JH, Yang JE, Lim CS, Lee JA, Lee YS, et al. Everolimus improves neuropsychiatric symptoms in a patient with tuberous sclerosis carrying a novel TSC2 mutation. Mol Brain. 2016;9(1):56.

10. Samueli S, Dressler A, Groppel G, Scholl T, Feucht M. Everolimus in infants with tuberous sclerosis complex-related west syndrome: first results from a single-center prospective observational study. Epilepsia. 2018;59(9):e142-e6.

11. Krueger DA, Capal JK, Curatolo P, Devinsky O, Ess K, Tzadok M, et al. Shortterm safety of mTOR inhibitors in infants and very young children with tuberous sclerosis complex (TSC): multicentre clinical experience. Eur J Paediatr Neurol. 2018;22(6):1066-107.

12. Northrup $H$, Krueger DA. International tuberous sclerosis complex consensus G. tuberous sclerosis complex diagnostic criteria update: recommendations of the 2012 linternational tuberous sclerosis complex consensus conference. Pediatr Neurol. 2013:49(4):243-54.

13. Wagner R, Riede FT, Seki H, Hornemann F, Syrbe S, Daehnert I, et al. Oral Everolimus for treatment of a Giant left ventricular Rhabdomyoma in a neonate-rapid tumor regression documented by real time 3D echocardiography. Echocardiography. 2015:32(12):1876-9.

14. NIH. Common Terminology Criteria for Adverse Events (CTCAE) 2017 Available from: https://ctep.cancer.gov/protocoldevelopment/electronic_ applications/docs/CTCAE_v5_Quick_Reference_8.5x11.pdf.

15. Mannick JB, Del Giudice G, Lattanzi M, Valiante NM, Praestgaard J, Huang B, et al. mTOR inhibition improves immune function in the elderly. Sci Transl Med. 2014;6(268):268ra179.

16. Strolin Benedetti M, Whomsley R, Baltes EL. Differences in absorption, distribution, metabolism and excretion of xenobiotics between the paediatric and adult populations. Expert Opin Drug Metab Toxicol. 2005; 1(3):447-71.

17. de Wildt SN, Kearns GL, Leeder JS, van den Anker JN. Cytochrome P450 3A: ontogeny and drug disposition. Clin Pharmacokinet. 1999;37(6):485-505.

18. Krueger DA, Care MM, Holland K, Agricola K, Tudor C, Mangeshkar P, et al. Everolimus for subependymal giant-cell astrocytomas in tuberous sclerosis. N Engl J Med. 2010;363(19):1801-11.

19. Franz DN, Agricola K, Mays M, Tudor C, Care MM, Holland-Bouley K, et al. Everolimus for subependymal giant cell astrocytoma: 5-year final analysis. Ann Neurol. 2015;78(6):929-38.

20. Mohamed I, Ethier G, Goyer I, Major P, Dahdah N. Oral everolimus treatment in a preterm infant with multifocal inoperable cardiac rhabdomyoma associated with tuberous sclerosis complex and a structural heart defect. BMJ Case Reports. 2014;2014:bcr2014205138.

21. Aw F, Goyer I, Raboisson MJ, Boutin C, Major P, Dahdah N. Accelerated cardiac Rhabdomyoma regression with Everolimus in infants with tuberous sclerosis complex. Pediatr Cardiol. 2017;38(2):394-400. 
22. Chang JS, Chiou PY, Yao SH, Chou IC, Lin CY. Regression of neonatal cardiac Rhabdomyoma in two months through low-dose Everolimus therapy: a report of three cases. Pediatr Cardiol. 2017;38(7):1478-84.

23. Demir HA, Ekici F, Yazal Erdem A, Emir S, Tunc B. Everolimus: a challenging drug in the treatment of multifocal inoperable cardiac rhabdomyoma. Pediatrics. 2012;130(1):e243-7.

24. Breathnach C, Pears J, Franklin O, Webb D, McMahon CJ. Rapid regression of left ventricular outflow tract rhabdomyoma after sirolimus therapy. Pediatrics. 2014;134(4):e1199-202.

25. Dogan V, Yesil S, Kayali S, Beken S, Ozgur S, Ertugrul I, et al. Regression of symptomatic multiple cardiac rhabdomyomas associated with tuberous sclerosis complex in a newborn receiving everolimus. J Trop Pediatr. 2015; 61(1):74-7.

26. Goyer I, Dahdah N, Major P. Use of mTOR inhibitor everolimus in three neonates for treatment of tumors associated with tuberous sclerosis complex. Pediatr Neurol. 2015;52(4):450-3.

27. Mlczoch E, Hanslik A, Luckner D, Kitzmuller E, Prayer D, Michel-Behnke I. Prenatal diagnosis of giant cardiac rhabdomyoma in tuberous sclerosis complex: a new therapeutic option with everolimus. Ultrasound Obstet Gynecol. 2015;45(5):618-21.

28. Oztunc F, Atik SU, Gunes AO. Everolimus treatment of a newborn with rhabdomyoma causing severe arrhythmia. Cardiol Young. 2015;25(7):1411-4.

29. Colaneri M, Quarti A, Pozzi M. Everolimus-induced near-resolution of giant cardiac rhabdomyomas and large renal angiomyolipoma in a newborn with tuberous sclerosis complex. Cardiol Young. 2016;26(5):1025-8.

30. Emir S, Hacisalihoglu S, Ozyoruk D, Ekici F, Degerliyurt A, Guven A, et al. Assessment of tumors in children with tuberous sclerosis: a single centre's experience. Turk Pediatri Ars. 2017;52(1):30-4.

31. Hoshal SG, Samuel BP, Schneider JR, Mammen L, Vettukattil JJ. Regression of massive cardiac rhabdomyoma on everolimus therapy. Pediatr Int. 2016; 58(5):397-9.

32. Kuki I, Kawawaki H, Okazaki S, Ehara E, Yoshida Y, Kunihiro N, et al. Efficacy and safety of everolimus in patients younger than 12 months with congenital subependymal giant cell astrocytoma. Brain and Development. 2018:40(5):415-20.

33. Hirsch RJ, Silverberg NB, Laude T, Weinberg JM. Tuberous sclerosis associated with congenital lymphedema. Pediatr Dermatol. 1999;16(5):407-8.

34. Voudris KA, Skardoutsou A, Vagiakou EA. Tuberous sclerosis and congenital lymphedema. Pediatr Dermatol. 2003;20(4):371-3.

35. Lucas $M$, Andrade $Y$. Congenital lymphedema with tuberous sclerosis and clinical Hirschsprung disease. Pediatr Dermatol. 2011;28(2):194-5.

36. Sukulal K, Namboodiri N. Congenital lymphedema: another unique and gender specific stigmata of tuberous sclerosis? Indian Pediatr. 2012;49(10):845.

37. Geffrey AL, Shinnick JE, Staley BA, Boronat S, Thiele EA. Lymphedema in tuberous sclerosis complex. Am J Med Genet A. 2014;164A(6):1438-42.

38. Prato G, Mancardi MM, Baglietto MG, Janis S, Vercellino N, Rossi A, et al. Congenital segmental lymphedema in tuberous sclerosis complex with associated subependymal giant cell astrocytomas treated with mammalian target of rapamycin inhibitors. J Child Neurol. 2014;29(9):NP54-7.

39. Hoshiai S, Oguma E, Sato Y, Konishi T, Minami M. Congenital focal lymphedema as a diagnostic clue to tuberous sclerosis complex: report of two cases diagnosed by ultrasound. Skelet Radiol. 2015;44(8):1165-8.

40. Jenkins D, McCuaig C, Drolet BA, Siegel D, Adams S, Lawson JA, et al. Tuberous sclerosis complex associated with vascular anomalies or overgrowth. Pediatr Dermatol. 2016;33(5):536-42.

41. Schubert-Bast S, Rosenow F, Klein KM, Reif PS, Kieslich M, Strzelczyk A. The role of mTOR inhibitors in preventing epileptogenesis in patients with TSC: current evidence and future perspectives. Epilepsy Behav. 2019;91:94-8.

42. Moavero R, Marciano S, Graziola F, Curatolo P. Combined targeted treatment in early onset epilepsy associated with tuberous sclerosis. Epilepsy Behav Case Rep. 2016:5:13-6.

Ready to submit your research? Choose BMC and benefit from:

- fast, convenient online submission

- thorough peer review by experienced researchers in your field

- rapid publication on acceptance

- support for research data, including large and complex data types

- gold Open Access which fosters wider collaboration and increased citations

- maximum visibility for your research: over $100 \mathrm{M}$ website views per year

At $\mathrm{BMC}$, research is always in progress.

Learn more biomedcentral.com/submissions 